\title{
Discrepant Electorates: The Inclusiveness of Electorates and Its Impact on the Representation of Citizens
}

\section{Daniele Caramani* and Oliver Strijbis}

Department of Political Science, University of St. Gallen, Rosenbergstrasse 51, CH-9000 St. Gallen, Switzerland

${ }^{*}$ Correspondence: daniele.caramani@unisg.ch, www.ipw.unisg.ch

This article addresses the democratically fundamental question of the inclusiveness of electorates and of its impact on citizens' representation. While the literature has focussed on the congruence between voters and representatives, it has neglected congruence issues between citizens and representatives. The article investigates comparatively this source of newly disenfranchised citizens in a globalised society with increasing mobility. On the one hand, electoral laws vary in their inclusion or exclusion of emigrants and in the right to vote to non-national residents (immigrants). On the other hand, naturalisation laws vary in the maintenance of nationality for nationals abroad (emigrants) and in their inclusion of non-national residents. We illustrate levels of 'discrepancy' between electorate and citizenship in 22 OECD countries qualitatively, by presenting differences of electoral and nationality laws, and quantitatively, by comparing the size of citizenship with that of the electorate, and the national and resident populations. We show that shifts between political and national communities are primarily due to naturalisation laws and that electoral laws have so far been unable to correct for the discrepancy.

\section{Introduction}

Early studies of forming democratic citizenship have focussed on the progressive inclusion of increasingly large segments of the population in the electorate: what classical sociologists and political scientists called 'incorporation' or 'participation.' With the full enfranchisement of the adult population and with the

\footnotetext{
${ }^{1}$ Rokkan (1999) speaks of incorporation in his model of democratisation based on four thresholds. Dahl (1971) presents a similar model of the first wave of democratisation along the two dimensions of liberalisation and participation. On these processes, see also Bendix (1977) and Magnette (2005).
} 
consolidation of national membership boundaries of political systems the analytical focus shifted toward Rokkan's third threshold of democratisation, that is, 'representation'. Since then, citizen-representative congruence has been at the heart of the empirical study of the quality of democratic representation, that is the degree to which voters' preferences are reflected among representatives. ${ }^{2}$ While early studies focussed on measures of proportionality, in the last years empirical research has addressed the correspondence between ideological preferences at the electorate level and at the policy-makers' level (see Deschouwer, 2005; Huber and Powell, 1994; Powell, 2000, 2004; Powell and Vanberg, 2000; Blais and Bodet, 2006; Golder and Stramski, 2010).

Yet, such work has been conducted under the assumption that electorates by and large reflect citizens. This assumption could be safely made under circumstances of consolidated national boundaries of political systems. The equation between citizenship and electorate is, however, increasingly problematic in a globalising society with increasing geographical mobility. The definition of citizenship merely through political rights (the right to vote) is restrictive and does not take into account other elements of citizenship such as social rights (Marshall, 1963) and nationality (Brubaker, 1992). According to a more encompassing view, the electorate is only a subgroup within the citizenry. The assumption of correspondence between citizens and voters-which probably has never been entirely realistic_-does certainly not apply to periods of elevated international mobility with life-long immigrants and emigrants transcending generations. The definition of citizenship and electorate under processes of supra-national integration and globalisation is today subject to 'restructuring' of boundaries very similar to that of other aspects of social and political life. ${ }^{3}$

Under these conditions, the phrase 'no taxation without representation' acquires new scope. An increasing share of citizens living and working 'abroad' lose political rights leading to a shift between citizenship and electorate. The claim this article makes is that issues of inclusiveness are as important as issues of representation and that therefore they should be revisited. By focussing on the quality of representation of electorates through representatives, the literature has forgotten issues of inclusiveness. It is this gap that the article aims to fill. While some authors have stressed the impact of exclusion on representation, such as the exclusion of the left-leaning Turkish population in Germany (Wüest, 2004), our article limits itself to discussing the issue of inclusion vs. exclusion of new segments of the globalised society. The article thus proposes to

\footnotetext{
${ }^{2}$ Accountability has been understood as the other main dimension of democratic representation (see, for example, Powell, 2000 and 2004; Mansbridge, 2003).

${ }^{3}$ For the most systematic treatment of the restructuring of the boundaries of political systems under pressure of supra-national integration, see Bartolini (2005).
} 
focus on the under-representation of entire social groups and not on the distribution of voters' preferences. In other words, the article wishes to shift the focus from problems of representation to issues of inclusion/exclusion.

The article is organised as follows. First, we elaborate on the notion of citizenship in relation to the electorate. Second, we present a typology of electorates and the potential causes of variations among types. We show that ideal-typically the right to vote can be granted to (1) nationals (including emigrants), (2) residents (including non-nationals) or a combination of both, i.e. (3) resident nationals only or (4) all residents and nationals. Third, we show qualitative variance in voting rights for non-national residents and national emigrants across 22 countries and, quantitatively, the discrepancy between citizenship and electorates in these countries. The conclusion discusses democratically important implications of the changing relationship between national and political community, and makes a practical proposal to overcome the shift between citizenship and political rights.

\section{Citizenship, electorates and representation}

The issue of inclusion deals with the relationship between citizenship and electorate. While political rights (the electorate) constitute a crucial dimension of citizenship, the latter concept is broader. Classical definitions of citizenship which we discuss below include the dimensions of nationality and social rights, as well as social duties. Accordingly, we define citizenship as the (potential) access to social rights that are granted to a group of people either through nationality (which applies to resident nationals and emigrants), ${ }^{4}$ or through residency (which applies to national and non-national residents) and, consequently, taxation duties. In the first case, we speak of a membership principle (the group of nationals) and in the second case, we speak of a territorial principle (the group of residents). In both cases citizenship is attached to a number of rights (but also duties) which an individual can make use of or claim. This entails a definition of citizenship which does not necessarily correspond to that of the electorate. On the contrary, it is likely that it goes well beyond that of the electorate. For example, immigrants have access to social provisions and pay taxes, but do not enjoy political rights. Furthermore, emigrants may profit from welfare provisions (or can always claim them by returning to the country) without enjoying political rights.

\footnotetext{
${ }^{4}$ Throughout this article, we speak of emigrants strictly speaking, i.e. referring to the first generation who left the home country (and not to second or further generations). It is therefore distinct from the concept of 'expatriates'. This choice is consistent with our definition of citizenship in terms of 'affected' principle that should be restricted to the first generation of emigrants.
} 
Our definition of citizenship is in line with Marshall's (1963) classical formulation of citizenship including civic, political and social rights. ${ }^{5}$ Our definition of citizenship is also consistent with the normative position based on the extent to which individuals are more or less directly affected by a country's policies (for example, Beckman 2006; Song 2009). Nationality has been the most important institution for the provision of citizenship rights. ${ }^{6}$ The reception of citizenship rights is, however, only partly dependent on nationality. In particular, civic rights are not bounded to nationality as they have developed towards human rights, which are increasingly granted on a global scale. Above all, social rights only partly depend on nationality as non-national residents in most Western countries get similar social provisions as national residents. The status of non-national residents, who have social but not political rights, has been described as 'denizenship' (Hammar, 1990). The concept of citizenship is therefore more encompassing than any operationalisation based on political rights. Political rights that define the electorate include, depending on the countries, a more or less wide proportion of citizens - as broadly defined above as the potential recipients of social rights either based on nationality or residency. There is therefore a varying discrepancy (across countries) between electorate and citizenship with some countries achieving a more or less complete coverage of the citizenship and some countries excluding a more or less large group.

The distinction between citizenship and voting rights had little impact on inclusion and exclusion issues during the peak of the nationalised state. This is because of the strong coincidence of the territorial boundaries (residency) and membership boundaries (nationality) during the peak of nationalisation. The closure of political, cultural, social and to some degree economic boundaries along the unitary state (Rokkan, 1999; Caramani, 2004) and the following cultural homogenisation (Gellner, 1983) have created a far-reaching congruence of rights and duties along the lines of the 'nation-state'. Only recent trends of globalisation and European integration have resulted in a decoupling of boundaries along different functional and territorial dimensions. The decoupling of territorial from national boundaries has important consequences. The increase in migration within and between the developed and developing world has had the effect

\footnotetext{
${ }^{5}$ The nation-state has been, and largely continues to be, the locus of political and social rights. This applies to a lesser extent to civic rights, which have an application across national borders independent of nationality. This is the reason why-as reiterated further down-we focus on the national level as opposed to the local or supra-national ones.

${ }^{6}$ It has been granted on two principles: ethnicity and residency (Brubaker, 1992). Which principle is dominant depends on conceptions of nationhood (see also Koopmans et al., 2005). While civic conceptions of nationhood foster legal citizenship laws that give nationality dependent on residence (jus soli), nationality is according to an ethnic conception of nationhood provided dependent on descent (jus sanguinis) (see also Weil, 2001).
} 
on a growing non-national resident population and on the size of the emigrant community, as well as on the size of the national community through increasing naturalisation rates.

The decoupling also affects the composition of electorates. This is because electoral rights are usually connected to nationality, residency or both. Having the right to vote does not entirely depend on being a national, as in some countries it (also) depends on residence: whether or not emigrants should have the right to vote, and whether or not non-national residents (immigrants) should be allowed to vote. In the age of globalisation and technological progress, the potential impact of the emigrants' votes has become considerable with elections being potentially decided 'from abroad'. Globalisation increases mobility, which affects the size of the emigrant community and strengthens the transnational bonds. Technological innovation has, among others, the effect that voting from abroad has become much easier. With electronic voting, space ceases being a decisive factor for the possibility to vote. As will be shown in the next section, electoral rights for emigrants vary considerably across countries and have a strong (potential) impact on the size and shape of the electorate.

Electoral laws also vary concerning the resident population. Increasingly, countries differ in whether they grant voting rights to non-national residents. Although a trend towards electoral rights for non-national residents can so far mainly be observed at the local level, a few countries granted the right to vote in national elections to all residents. ${ }^{7}$ The effect the expansion of the electoral right to non-nationals has on the shape and size of the electorate depends on the size of the foreign community in a given country. The impact of the electoral rights to non-national residents on the variance in the electorates across countries depends on the migration flows and on naturalisation laws. All this increases the discrepancy between electorate and citizenship, as well as the extent to which this discrepancy varies across countries. According to our definition of citizenship it leads to newly disenfranchised groups, namely emigrants and immigrants. Examples of citizens who lost the right to vote 'back home' but did not acquire it in the receiving country are numerous (for example, Turks in Germany), with some cases of explicit discouragement from both the sending and the receiving country. ${ }^{8}$

\footnotetext{
${ }^{7}$ We limit our discussion to the right to vote at the national level and exclude provisions for political rights for non-national residents at the local or regional level. We also exclude political rights in foreign countries due to supra-national democratic bodies such as the European Parliament. As for varying registration rules, these apply only to Australia, Canada and the USA. All figures in this paper are based on the number of registered voters unless specified otherwise.

${ }^{8}$ We deliberately do not discuss the exclusion of other social groups such as minors, prisoners and mentally ill persons for which only the USA includes particular provisions. As Uggen and Manza
} 
Our article is not concerned with whether or not inclusiveness affects the voter-representative relationship. The quality of representation is in principle independent from levels of inclusiveness. ${ }^{9}$ If the preferences of emigrants and immigrants systematically differ from the national resident ones, whether these groups keep or receive the right to vote (through naturalisation or the electoral law) matters for representation issues. However, the claim this article makes is limited to the fact that the analysis of the quality of representation can no longer afford to use the shortcut of equating citizenship with the electorate as increasingly large and permanent segments of the citizenship are excluded (rather than included) from access to political rights. It is this discrepancy between citizenship and electorate- a problem of inclusion rather than representation-with which this article is concerned.

\section{A typology of electorates}

\subsection{Four types of electorate}

In developed democracies, the shape of the electorate can ideal-typically be summarised in four different types depending on whether or not the electoral right is given to non-national residents and/or expatriates. Similar to Bauböck (2005, p. 685), who distinguishes between four perspectives on 'expansive electoral rights', we distinguish four types of electorate:

- The national-resident electorate includes nationals living in their home country. It excludes non-national immigrants and nationals who emigrated. It is the most restrictive type of electorate as, according to this ideal-type, only nationals living within the borders of 'their' state are entitled to vote. The closest empirical case of this type is Canada. ${ }^{10}$

- The national electorate includes all nationals independently of whether they are resident in their 'homeland' or not. Voting rights are granted to nationals in the home countries and to nationals who emigrated abroad. The principle here is purely based on membership. The closest empirical case of this type is Italy. ${ }^{11}$

\footnotetext{
(2002) note, 'the United States is virtually the only nation to permanently disenfranchise ex-felons as a class in many jurisdictions, and the only country to limit the rights of individuals convicted of offenses other than very rare treason or election-related crimes'.

${ }^{9}$ In theory, one can also achieve perfect representation when no citizen has the right to vote.

${ }^{10}$ For all these examples, qualifications are in order. In Canada, for example, emigrants have the right to vote from abroad during the first five years after emigration.

${ }^{11}$ Italy only recently introduced provisions for voting from abroad linked to registration in a consulate. Before, emigrants had to travel back to Italy to make use of their right to vote.
} 
- The resident electorate includes all individuals who are resident in a given country independently of their nationality. Whether or not they are nationals, people living in a country have the right to vote. The principle here is purely territorial. This includes resident nationals and non-national immigrants. The closest empirical case of this type is New Zealand. ${ }^{12}$

- The national and resident electorate includes all nationals (whether or not they live in the home country) as well as all residents (nationals and foreigners). These are the most inclusive electoral rules extending political rights not only to emigrants but also to non-national residents. Both membership and territory principles apply. The closest example of this type is Britain but, strictly speaking, there are no empirical cases. ${ }^{13}$

These types of electorate are listed from the most restrictive to the most extensive. The two principles that apply are the membership and the territorial one. Their combination can be depicted as in Figure 1. The two types are pure in the sense that they are based on either territorial or membership principles, whereas the two are mixed in the sense that they combine both principles. Below we will show the degree to which developed democracies fit into these ideal-types and, consequently, the degree to which they differ. We do not rely only on the qualitative description of the rules, but also present quantitative data on the actual shape and size of the electorates. For the moment being, we concentrate on types and sources of variation between countries.

\subsection{Sources of cross-country variation}

Electorates across countries vary because of differing provisions in two types of laws: first, the nationality law and, second, the electoral law. In addition, electorates vary because of differences in immigration and emigration rates.

(1) Nationality laws are relevant for variations in electorates, and in the degree of discrepancy between citizenship and electorate, as nationality automatically gives access to political rights. Nationality laws affect membership. First, nationality laws determine the size of emigrant electorate in that it rules on the maintenance of nationality after leaving the country. ${ }^{14}$ Second,

\footnotetext{
${ }^{12}$ This is due to the very short period of time during which emigrants keep the right to vote from abroad (three years). The minimum requirement for qualifying to vote for residents is one year for non-nationals.

${ }^{13}$ British nationals living abroad can vote for as long as the first 15 years after emigration. Furthermore, the category of 'residents' is very expansive as it includes all resident Commonwealth nationals (as well as Irish nationals).

${ }^{14}$ This applies more to further generations than to the first generation of emigrants.
} 


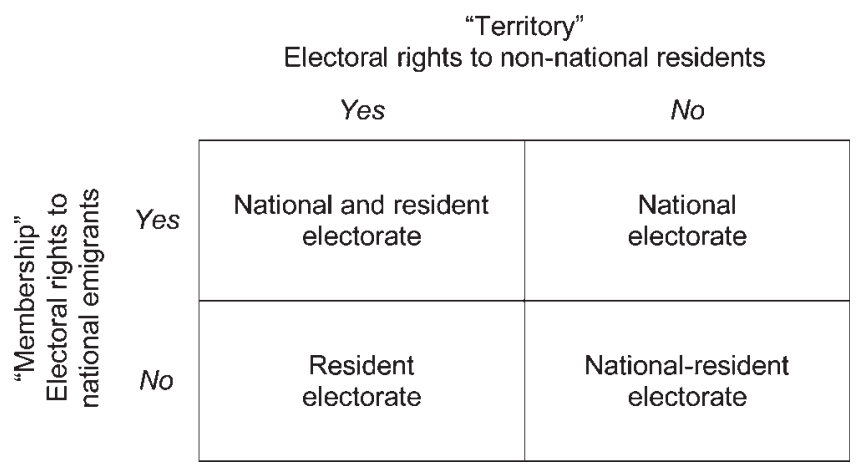

Figure 1 Four types of electorate in modern democracies

nationality (here, strictly speaking, naturalisation laws) determines the size of non-national resident communities (immigrants) in that it rules on the access to nationality for resident immigrants (again also for further generations). Nationality laws affect the extent to which more or less large immigrant/emigrant groups get (or keep) nationality and consequently political rights.

(2) Electoral laws are relevant for variation in electorates, and in the degree of discrepancy between citizenship and electorate, as they grant the right to vote. Electoral laws affect territoriality. First, electoral laws rule on the right to vote within the country for non-nationals. It is through the electoral law that political rights are given to residents who are not nationals (immigrants). Second, electoral laws rule on the right to vote outside the country for nationals. It is through the electoral law that political rights are given to nationals who are no longer resident (emigrants). Electoral laws affect the extent to which more or less large immigrant/emigrant groups get (or keep) political rights (independently of nationality).

(3) The interaction between migration rates and the two types of law is crucial, as the data in the quantitative part of the article (next section) show. Figure 2 summarises the discussion. What appears to be crucial is the interaction between rates of immigration/emigration (and therefore the size of nonnational resident groups and nationals abroad) on the one hand, and the legal framework which makes it possible to access the right to vote, on the other hand. As mentioned, there are two possibilities for getting the right to vote: through nationality on the electoral law.

The groups of non-national residents and emigrants can be either small or large (we simplify for the sake of the argument). We ignore the possibility in 


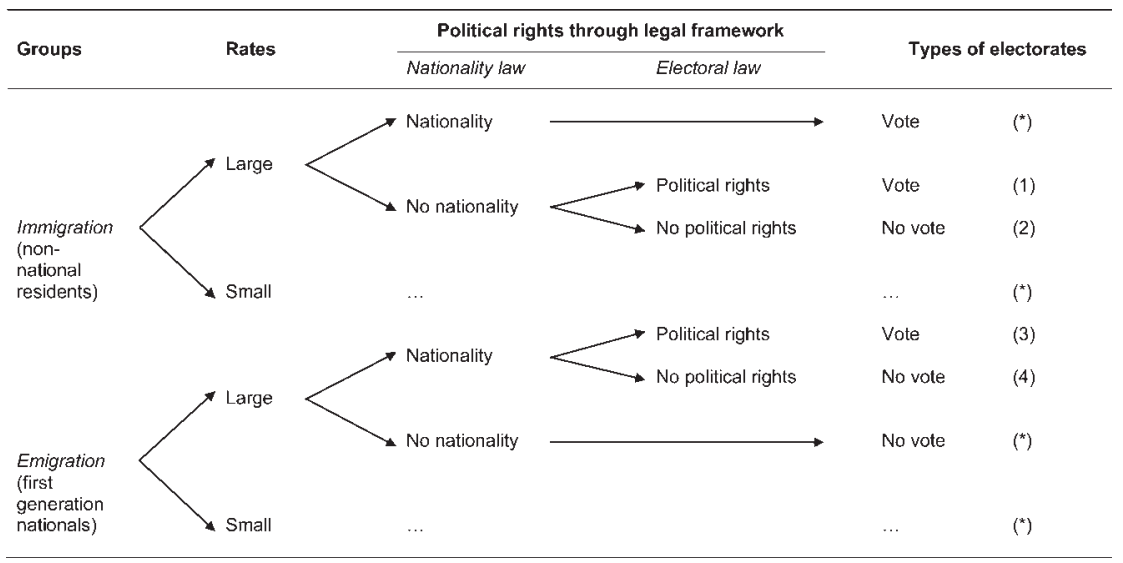

Figure 2 Access to political rights for non-national residents (immigrants) and nationals abroad (emigrants). Combination 1-4: resident electorate (New Zealand); Combination 1-3: national and resident electorate (Britain); Combination 2-3: national electorate (Italy, Portugal); Combination 2-4: national-resident electorate (Canada); ${ }^{*}$ ) cases in which citizenship and electorate correspond

which they are small as this does not affect the level of discrepancy between citizenship and electorate. If there are only very little numbers of immigrants and emigrants, citizenship and electorate correspond. They also correspond if immigrants are given the nationality since citizens acquire automatically the right to vote. Also when emigrants lose nationality (and therefore claims to social rights) the two correspond. ${ }^{15}$ The interesting cases in the perspective of this article are those in which one finds large numbers of either immigrants or emigrants or both. In this case we do not have a citizenship corresponding to the electorate as many nationals may not have the right to vote (because they live abroad) and many non-nationals living in the country may not have the right to vote. If there are large numbers of emigrants and/or immigrants, citizenship and electorate do not correspond unless the legal framework corrects for it (either through the nationality law or the electoral law). ${ }^{16}$ The last column of the figure shows how the combination of legal provisions for the right to vote of emigrants and immigrants combine to determine the four types of electorate.

\footnotetext{
${ }^{15}$ Note that losing the nationality does not only depend on the country of origin but also on the host country which may require emigrants to give up their nationality of origin.

${ }^{16}$ The figure simplifies a much more complicated story in which access to political rights for nationals living abroad is made difficult by registration requirements. This is discussed and illustrated below in the quantitative part of the analysis.
} 


\section{Discrepant electorates in 22 OECD countries}

We divide the empirical analysis in two parts. First, qualitatively, we carry out the analysis of nationality laws and electoral laws, and how they empirically vary across countries. Second, quantitatively, we propose an analysis of the discrepancy between citizenship and electorate based on the size of emigrant and non-national resident groups.

\subsection{Qualitative analysis: naturalisation laws and electoral laws}

As we have seen above, it is possible to acquire voting rights either through nationality laws or through electoral laws. The first includes individuals in the membership of nationals or excludes them. The second includes individuals resident in a territory (non-national citizens) and those residents abroad or excludes them. What appears from the comparative information collected for 22 OECD countries presented in Table 1 is that countries vary above all with regard to nationality laws and hardly vary with regard to electoral laws.

On the one hand, in only very few countries do electoral laws allow nonnational residents (immigrants) to vote in national or federal elections. The only such case is New Zealand. There are other two cases in which specific types of 'nonnationals' are allowed to vote: first, Brazilians in Portugal under a number of special conditions; second, British nationals in Ireland and third, Commonwealth and Irish nationals in the UK. In no other country in the sample considered here can resident foreigners participate in national or federal elections. On the other hand, almost all countries allow their national emigrants to maintain the right to vote. As we see from Table 1 most countries allow their nationals abroad to keep the right to vote either indeterminately or for a more or less long period of time. In this regard, the variation is quite large. Out of the 22 countries, 15 allow expatriates to maintain the right to vote without time limits. There is one country that does not allow its nationals to vote if living abroad: Ireland. ${ }^{17}$ Among the remaining six countries, there are three that allow keeping the right to vote for a short period of time (New Zealand for three years, Canada for five and Australia for six). Portugal allows emigrants to vote in national elections for up to ten years after emigration. The impact of this variation on the discrepancy between citizenship and electorate obviously depends on the size of both immigration and emigration. We will deal with the interaction between laws and rates of migrations in the quantitative analysis.

\footnotetext{
${ }^{17}$ The exception being diplomats and military. Considering the size of Irish emigration to the USA, granting emigrants the right to vote would mean that the election could be decided overseas, even if in this case this applies primarily to second and further generations.
} 
Table 1 Electoral rights at the national level for non-national residents (immigrants) and nationals abroad (emigrants) in 22 OECD countries

\begin{tabular}{|c|c|c|c|c|}
\hline Country & $\begin{array}{l}\text { Electoral rights for } \\
\text { nationals abroad } \\
\text { (emigrants) }^{\mathrm{a}}\end{array}$ & $\begin{array}{l}\text { Electoral rights } \\
\text { for non-national } \\
\text { residents } \\
\text { (immigrants) }\end{array}$ & $\begin{array}{l}\text { Access to } \\
\text { nationality } \\
\text { (MIPEX } \\
\text { index, } \\
0-100 \text { ) }\end{array}$ & $\begin{array}{l}\text { Share of } \\
\text { foreign-born } \\
\text { residents } \\
(2000 / 01)\end{array}$ \\
\hline Australia & For the first six years & No & NA & 23.1 \\
\hline Austria & Yes & No & 22 & 10.5 \\
\hline Belgium & Yes & No & 71 & 10.3 \\
\hline Canada & For the first five years & No & 67 & 18.1 \\
\hline Czech Republic & Yes & No & 50 & 4.2 \\
\hline Denmark & Yes & No & 33 & 5.8 \\
\hline Finland & Yes & No & 44 & 2.6 \\
\hline Germany & For the first 25 years & No & 38 & 12.5 \\
\hline Iceland & Yes & No & NA & NA \\
\hline Ireland & $\mathrm{No}^{\mathrm{b}}$ & Partlyc & 62 & 8.7 \\
\hline Italy & Yes & No & 33 & 2.5 \\
\hline Japan & Yes & No & NA & NA \\
\hline Luxembourg & Yes & No & 45 & 33.2 \\
\hline The Netherlands & Yes & No & 51 & 10.1 \\
\hline New Zealand & For the first three years & Yes & NA & 17.2 \\
\hline Norway & Yes & No & 39 & 6.8 \\
\hline Portugal & For the first ten years $^{\mathrm{d}}$ & Partlyc & 69 & 5.1 \\
\hline Spain & Yes & No & 41 & 5.3 \\
\hline Sweden & Yes & No & 71 & 11.5 \\
\hline Switzerland & Yes & No & 44 & 21.9 \\
\hline UK & For the first 15 years & Partlyc & 62 & 7.9 \\
\hline USA & Yes & No & NA & 11.0 \\
\hline
\end{tabular}

Note: NA, information not available.

aln most countries, emigrants usually need to register as voters (Green, 2007).

${ }^{b}$ Only diplomats and military.

'In the case of Ireland, British residents are also allowed to vote for Dáil elections. In Portugal, Brazilian citizens with special rights acquire voting rights and in the UK, these rights include Commonwealth and Irish citizens.

${ }^{\mathrm{d} N o t}$ more than 15 years in the EU or a Portuguese-speaking country. Additionally, they have to stay at least 30 days in Portugal in the last five years and speak Portuguese (Costa Lobo, 2007, p. 84).

Sources: Data on emigrants' voting rights from IDEA (2007); electoral rights for immigrants and access to nationality from MIPEX of the British Council and Migration Policy Group (2007); data on foreign-born population from OECD (2006).

Contrary to electoral laws, nationality laws vary a great deal across countries in the extent to which they give access to nationality and, consequently, voting rights. Nationality laws are the set of rules through which the conditions for the gain or loss of nationality are set. For clarity we will speak in general of 'nationality law' to indicate the extent to which emigrants maintain their nationality of origin and of 'naturalisation law' to indicate the extent to which immigrants acquire the new nationality. Most countries do not deprive emigrants of their nationality (even after generations, although some do from the third). Nationality 
laws therefore do not vary a great deal with regard to national emigrants. ${ }^{18}$ They do vary, however, a great deal with regard to the naturalisation of non-national resident citizens. While naturalisation laws based on jus sanguinis are very closed towards ethnically distinct immigrants - and therefore generate large numbers of non-national residents-countries based on jus soli tend to be much more open in the way they naturalise the majority of their immigrant residents. Good examples of 'hard-to-get' naturalisation are Austria and Switzerland. The third column in Table 1, however, points to other countries for which naturalisation for non-national residents is difficult. Using the Migrant Integration Policy index (MIPEX) that operationalise the easiness with which single nationalities can be acquired, we see that besides Austria and Switzerland, also Germany, Denmark and Finland (as well as Italy and Spain) have naturalisation laws unfavourable to the incorporation of non-nationals in the electorate through the nationality law.

The discussion so far leads us to conclude that electoral laws vary little with the exception of Ireland (as far as the electoral law on emigrants is concerned) and New Zealand (as far as the electoral law concerning immigrants is concerned). With regard to the acquisition of nationality and therefore the automatic access to political rights, again we find little variation concerning nationality law (emigrants). However, there is a large variation in naturalisation laws (immigrants). This information leads us to formulate the hypothesis that differences in the levels of discrepancy (between citizenship and electorates) are primarily caused by variations in naturalisation laws, and amplified by a large influx of immigrants.

\subsection{Quantitative analysis: size of emigration and immigration}

In this section we proceed in three steps. First, we describe citizenship in 21 countries. ${ }^{19}$ Then, we describe electorates. Finally, we describe the discrepancy between citizenship and electorate and interpret variations in the levels of discrepancy with reference to (1) nationality and electoral laws (mentioned above) and (2) rates of immigration and emigration.

The data on which we can draw are official register data from National Statistical Offices and from the OECD. Census data contain the number of residents and the number of non-national residents by age cohorts. The size of the

\footnotetext{
${ }^{18}$ Regulations regarding the maintenance of nationality for emigrants are made more complicated by conditions set by the receiving country and the possibility of having a double nationality. A good example is the impact on the German naturalisation law on the propensity of Turkish immigrants to resign from their former nationality before the change of the German naturalisation law in 2002.

${ }^{19}$ We must unfortunately exclude New Zealand from this part of the analysis because of unreliable information.
} 
electorates has been derived from data on electoral results. The data on emigrant communities had, in several cases, to be estimated. The most valid (and in many cases only) estimates on the size of the emigrant community have been calculated by the OECD for the year 2000 (2001 for Italy). They only include the number of emigrants in other OECD countries and should therefore be interpreted as the lower bound of the real number. The data further estimate the number of emigrants at the age of 15 or older and do therefore slightly overestimate the share of emigrants at voting age.

Table 2 presents some basic information about citizenship, defined as access to social rights, for our sample of 21 countries. Let us remember that we consider as citizens all those who possess the nationality of the country (whether they live in the country or not) plus those who live in the country (whether they are nationals or not). It is interesting to see that there is a great deal of variation in the composition of citizenship in these countries. There are six countries that have a proportion of non-national residents (immigrants) between 5 and 10\% (UK, Belgium, Germany, USA, Ireland and Sweden). There are two countries with much higher proportions: Austria and Switzerland (about 18\%). And, finally, there is Luxembourg with $33 \%$ of non-national resident citizens (mostly due to European institutions and financial centres). For the remaining 12 countries, the proportion of non-national residents is below $5 \%$. Some variation exists also in the proportion of citizens who live abroad, that is national emigrants. The large exception here is Ireland with $22.5 \%$ of its citizens living overseas. Iceland and Portugal have a share of emigrants of around $10-13 \%$. Three countries have rates of nationals living abroad of 5-8\% (Finland, Italy, Luxembourg and the UK). The remaining 14 countries have rates of emigrants of less than $5 \%$.

In Table 3 countries are ranked according to the degree of discrepancy between citizenship and electorates (last column). The simple indicator we use here is the percentage of citizens without voting rights, that is, those not included in the electorate. It is a measure of 'political exclusion': the larger the percentage, the more exclusive the franchise. On top of the table, Luxembourg stands out with nearly $40 \%$ of citizens-i.e. mostly non-national residents (immigrants)—excluded from voting rights. Table 4 informs us about the composition of this excluded segment of the citizenship. Around $85 \%$ of the disenfranchised citizens in Luxembourg are immigrants and only $15 \%$ are nationals who emigrated. Two very similar cases are Austria and Switzerland. For the two Alpine cases, too, there is a large proportion of citizens who do not have the right to vote in federal elections (about 22\% in both cases). This is one out of five citizens. As for Luxembourg, disenfranchised citizens are mostly (above 
Table 2 Citizenship in 21 OECD countries

\begin{tabular}{|c|c|c|c|c|c|}
\hline Country & $\begin{array}{l}\text { Adult citizen- } \\
\text { ship } \\
\text { (absolute) }\end{array}$ & $\begin{array}{l}\text { Non-national } \\
\text { residents } \\
\text { (immigrants) }\end{array}$ & $\begin{array}{l}\text { Nationals abroad } \\
\text { (emigrants) (as } \\
\% \text { of citizens) }\end{array}$ & $\begin{array}{l}\text { Resident } \\
\text { nationals }\end{array}$ & Total \\
\hline Japan & $104,353,921$ & 1.1 & 0.6 & 98.4 & 100.0 \\
\hline Czech Republic & $8,413,143$ & 1.8 & 2.7 & 95.6 & 100.0 \\
\hline Canada & $25,326,533$ & 0.8 & 4.1 & 95.1 & 100.0 \\
\hline Spain & $34,355,265$ & 3.8 & 2.5 & 93.7 & 100.0 \\
\hline Australia & $14,882,361$ & 4.9 & 1.8 & 93.3 & 100.0 \\
\hline Norway & $3,564,658$ & 4.1 & 3.4 & 92.4 & 100.0 \\
\hline Finland & $4,335,367$ & 1.8 & 6.1 & 92.1 & 100.0 \\
\hline USA & $210,088,689$ & 7.6 & 0.4 & 92.0 & 100.0 \\
\hline Sweden & $7,151,617$ & 5.4 & 2.9 & 91.7 & 100.0 \\
\hline Denmark & $4,361,200$ & 4.4 & 4.0 & 91.6 & 100.0 \\
\hline The Netherlands & $13,071,282$ & 3.9 & 4.7 & 91.3 & 100.0 \\
\hline Italy & $50,810,452$ & 2.0 & 7.2 & 90.8 & 100.0 \\
\hline UK & $48,720,576$ & 5.6 & 6.6 & 87.8 & 100.0 \\
\hline Belgium & $8,477,923$ & 8.6 & 3.8 & 87.6 & 100.0 \\
\hline Germany & $69,992,647$ & 8.3 & 4.2 & 87.6 & 100.0 \\
\hline Iceland & 223,839 & 3.3 & 10.3 & 86.4 & 100.0 \\
\hline Portugal & $9,531,004$ & 2.6 & 13.3 & 84.1 & 100.0 \\
\hline Switzerland & $5,969,867$ & 18.2 & 4.4 & 77.4 & 100.0 \\
\hline Austria & $7,548,342$ & 18.0 & 4.8 & 77.2 & 100.0 \\
\hline Ireland & $3,516,392$ & 6.0 & 22.5 & 71.4 & 100.0 \\
\hline Luxembourg & 363,846 & 33.3 & 7.5 & 59.3 & 100.0 \\
\hline
\end{tabular}

Notes: Countries are ordered by size of resident nationals. Citizenship is defined as the sum of all nationals (in country and abroad) and all residents in the country (whether nationals or not). All figures exclude youngsters below 18 years of age. The interpretation of such figures must allow for bias caused by prisoners and mentally ill persons who, in some countries, are excluded from voting rights. New Zealand is excluded because of unreliable information.

Sources: National Statistical Offices; Dumont Lemaître (2005); OECD (2006). Because in the case of the Czech Republic and Spain the estimates have been unrealistically low, the share of emigrants is estimated as the deviation of the electorate from the national residents.

$80 \%$ for both Austria and Switzerland) non-national residents. ${ }^{20}$ Additional similar cases are Belgium, Germany, Sweden, Norway, Finland and Italy. For these countries we see a lower level of discrepancy, that is, exclusion. However, the composition of the excluded citizens is very similar to that of Luxembourg, Switzerland and Austria, with more than $65 \%$ of the excluded citizens being immigrants. $^{21}$

\footnotetext{
${ }^{20}$ The same is true for Spain and the Czech Republic. Because in these cases the OECD estimates of the emigrant community have been unrealistically low, it has been estimated as the deviation of the electorate from the national residents. In reality, however, the share of emigrants without the right to vote is still somewhat higher implying that slightly $<100 \%$ of the disenfranchised are immigrants.

${ }^{21}$ Incomplete data sources do not allow us to comment on Australia, Canada and New Zealand.
} 
Table 3 Electorates in 21 OECD countries

\begin{tabular}{lrrrl}
\hline Country & Citizenship & Electorate & Difference & $\begin{array}{l}\text { Difference (as \% } \\
\text { of total } \\
\text { citizenship) }\end{array}$ \\
\hline Luxembourg & & & & \\
Switzerland & 363,846 & 221,103 & 142,743 & 39.2 \\
Austria & $5,969,867$ & $4,628,782$ & $1,341,085$ & 22.5 \\
Canada & $7,548,342$ & $5,912,592$ & $1,635,750$ & 21.7 \\
Ireland & $25,326,533$ & $21,243,473$ & $4,083,060$ & 16.1 \\
Australia & $3,516,392$ & $3,002,173$ & 514,219 & 14.6 \\
Germany & $14,882,361$ & $12,708,837$ & $2,173,524$ & 14.6 \\
Belgium & $69,992,647$ & $61,432,868$ & $8,559,779$ & 12.2 \\
UK & $8,477,923$ & $7,570,637$ & 907,286 & 10.7 \\
Denmark & $48,720,576$ & $44,403,238$ & $4,317,338$ & 8.9 \\
The Netherlands & $4,361,200$ & $3,998,957$ & 362,243 & 8.3 \\
USA & $13,071,282$ & $12,035,935$ & $1,035,347$ & 7.9 \\
Portugal & $210,088,689$ & $194,327,000$ & $15,761,689$ & 7.5 \\
Sweden & $9,531,004$ & $8,902,713$ & 628,291 & 6.6 \\
Norway & $7,151,617$ & $6,722,163$ & 429,454 & 6.0 \\
Iceland & $3,564,658$ & $3,358,856$ & 205,802 & 5.8 \\
Japan & 223,839 & 211,289 & 12,550 & 5.6 \\
Spain & $104,353,921$ & $100,433,798$ & $3,920,123$ & 3.8 \\
Italy & $34,355,265$ & $33,045,318$ & $1,309,947$ & 3.8 \\
Finland & $50,810,452$ & $49,358,947$ & $1,451,505$ & 2.9 \\
Czech Republic & $4,335,367$ & $4,220,951$ & 114,416 & 2.6 \\
& $8,413,143$ & $8,264,484$ & 148,659 & 1.8 \\
\hline
\end{tabular}

Notes: Countries are ordered by level of discrepancy as a percentage of citizenship. New Zealand is excluded because of missing information. As far as Australia, Canada and the USA are concerned, figures include only registered voters. In the USA figures exclude felons and prisoners, 4,686,539 citizens in 2000 (or about 2.3\% of the electorate according to Uggen and Manza, 2002, pp. 778 and 797).

Sources: National Statistical Offices; OECD (2006); Dumont and Lemaître (2005).

Things look different for Portugal and Ireland, as well as for Denmark, the Netherlands and Japan. Portugal does not have a very high rate of discrepancy $(6.6 \%)$. It is only slightly higher for Denmark and the Netherlands (about $8 \%$ ) while for Japan it is $3.8 \%$. On the contrary, the rate is quite high for Ireland (14.6\%). What these five cases have in common is that the proportion of citizens without voting rights are to a large extent national emigrants who lost the right to vote. The proportion of emigrants among the disenfranchised citizens is around 75\% for Ireland, 60\% for Portugal, and around $50 \%$ for Denmark and the Netherlands. Another country for which the proportion is high is Japan: above $70 \%$ of the discrepancy (which, 
Table 4 Composition of discrepant electorates in 18 OECD countries

\begin{tabular}{|c|c|c|c|c|c|c|c|}
\hline Country & $\begin{array}{l}\text { Difference } \\
\text { citizenship } \\
\text { - electorate }\end{array}$ & $\begin{array}{l}\text { Difference (as } \\
\% \text { of } \\
\text { citizenship) }\end{array}$ & $\begin{array}{l}\text { Non-national resi- } \\
\text { dents } \\
\text { (immigrants) }\end{array}$ & $\begin{array}{l}\text { Non-national resi- } \\
\text { dents (as \% of } \\
\text { difference) }\end{array}$ & $\begin{array}{l}\text { Nationals } \\
\text { abroad } \\
\text { (emigrants) }\end{array}$ & $\begin{array}{l}\text { Emigrants } \\
\text { without vote }\end{array}$ & $\begin{array}{l}\text { Emigrants } \\
\text { without vote (as } \\
\% \text { of difference) }\end{array}$ \\
\hline Luxembourg & 142,743 & 39.2 & 121,058 & 84.8 & 27,164 & 21,685 & 15.2 \\
\hline Switzerland & $1,341,085$ & 22.5 & $1,084,645$ & 80.9 & 262,456 & 256,440 & 19.1 \\
\hline Austria & $1,635,750$ & 21.7 & $1,357,388$ & 83.0 & 366,024 & 278,362 & 17.0 \\
\hline Ireland & 514,219 & 14.6 & 211,742 & 41.2 & 792,316 & 385,000 & 74.9 \\
\hline Germany & $8,559,779$ & 12.2 & $5,774,762$ & 67.5 & $2,933,757$ & $2,785,017$ & 32.5 \\
\hline Belgium & 907,286 & 10.7 & 727,161 & 80.1 & 321,544 & 180,125 & 19.9 \\
\hline Denmark & 362,243 & 8.3 & 191,261 & 52.8 & 173,009 & 170,982 & 47.2 \\
\hline The Netherlands & $1,035,347$ & 7.9 & 515,156 & 49.8 & 616,909 & 520,191 & 50.2 \\
\hline Portugal & 628,291 & 6.6 & 244,526 & 38.9 & $1,268,726$ & 383,765 & 61.1 \\
\hline Sweden & 429,454 & 6.0 & 386,977 & 90.1 & 206,604 & 42,477 & 9.9 \\
\hline Norway & 205,802 & 5.8 & 147,125 & 71.5 & 122,079 & 58,677 & 28.5 \\
\hline Iceland & 12,550 & 5.6 & 7450 & 59.4 & 23,070 & 5,100 & 40.6 \\
\hline UK & $4,317,338$ & 8.9 & $2,710,900$ & 62.8 & $3,229,676$ & $1,606,438$ & 37.2 \\
\hline Japan & $3,920,123$ & 3.8 & $1,121,446$ & 28.6 & 575,992 & 2,798,677 & 71.4 \\
\hline Spain & $1,309,947$ & 3.8 & $1,309,947$ & 100.0 & 849,298 & 0 & 0.0 \\
\hline Italy & $1,451,505$ & 2.9 & $1,003,451$ & 69.1 & $3,649,377$ & 448,054 & 30.9 \\
\hline Finland & 114,416 & 2.6 & 76,425 & 66.8 & 265,245 & 37,991 & 33.2 \\
\hline Czech Republic & 148,659 & 1.8 & 148,659 & 100.0 & 241,529 & 0 & 0.0 \\
\hline
\end{tabular}

Note: This table does not include the USA, Australia and Canada for which the data on the composition of the discrepancy between citizenship and electorate are strongly influenced by registration rules which make the interpretation of data difficult. Data on the number of registered voters are not available. For the US special regulations with regard to prisoners, see notes to Table 3. New Zealand is excluded because of unreliable data. For Spanish and Czech figures, see footnote 19. 
however, is a small one) is due to national emigrants. This is explained by the very low immigration rates in Japan. ${ }^{22}$

These figures are summarised graphically in Figure 3. The level 'zero' indicates the number of voters according to official electoral registers. The four bars indicate deviations from the electorate. The white bars correspond to our definition of citizenship: all nationals (wherever they live) plus all those living in the country and paying taxes there (whatever their nationality). In some countries, such as Luxembourg, Switzerland and Austria, there are many more citizens than voters. The striped bars show that in most cases there are more nationals than voters and, therefore, that there are always nationals without the right to vote (those living abroad). The dotted bars indicate that the number of nationals living in the country is usually only a part of the electorate, although a very large one obviously. Negative bars indicate here that the group of national residents is smaller than the electorate. This means that in these countries emigrants have the right to vote, with the exception of Ireland where the discrepancy between the share of national residents and the electorate is due to the voting rights of British nationals. The gray bars, finally, indicate that there are countries such as Luxembourg, Austria and Switzerland (but also Germany) where the discrepancy between citizens and voters is caused by the exclusion of immigrants who do not have voting rights through the electoral law and who have a difficult access to nationality (and through that to voting rights).

In these cases we see very clearly the interaction at play between immigration flows and nationality (or naturalisation) laws. The largest discrepancies between citizenship and electorate exist in those cases in which large rates of immigration are combined with restrictive nationality laws. As seen above, this is the factor that really varies across countries. Whereas electoral laws hardly ever allow nonnational residents to vote, naturalisation may or may not give access to voting rights. It is therefore the interaction between high rates of immigration and restrictive naturalisation laws that explain most of the cross-country variation of discrepancy between electorate and citizenship. The same cannot be said to the same extent for national emigrants. Here rates count, too, but as we have seen the variation in electoral laws (granting voting rights to emigrants) is small.

\section{Conclusion}

This article has shown that the quality of democracy in a globalised world depends to a large extent on the degree to which citizens are included or excluded

\footnotetext{
${ }^{22}$ Other countries with a quite large segment of expatriates among the excluded citizens are Iceland, Italy, Finland and the UK. The proportion of emigrants in the segment of citizenship without voting rights is above $30 \%$ for all these countries.
} 


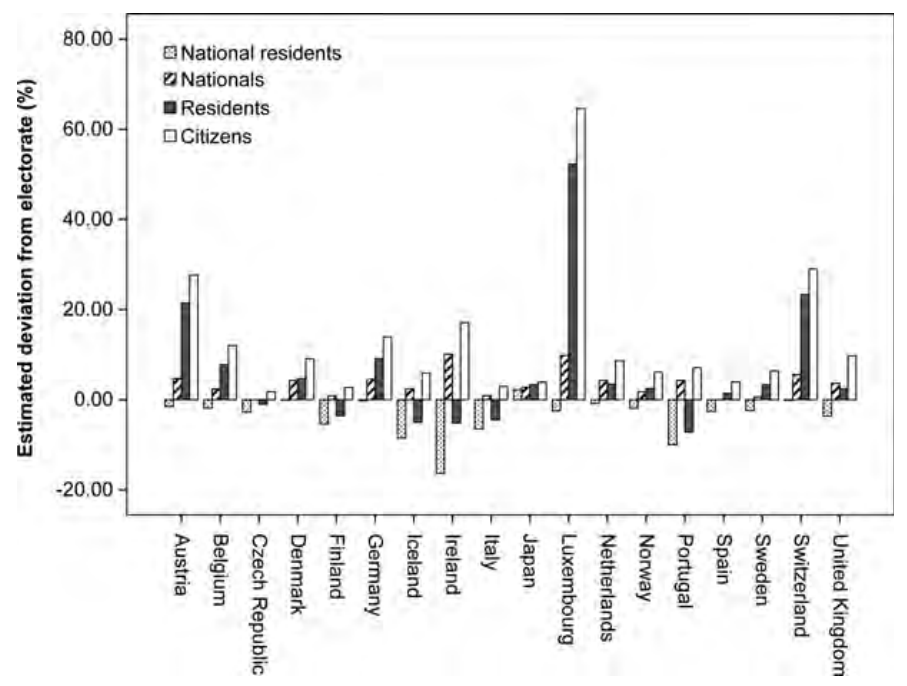

Figure 3 Citizenship and electorate in 18 OECD countries

in the representation circuit. Based on a broad definition of citizenship we have shown that in an increasingly mobile society important segments of the citizenry are losing basic political rights. This has far-reaching consequences for democracy in institutional settings in which the territorial nation-state still guides formal democratic rights but increasingly looks out of phase with a transnational economy and society. The more or less large discrepancy between citizenship and electorate makes this one-to-one equivalence between citizenship and electorate problematic. The article therefore questions the 'denominator', whether using electorates can replace citizenship. Theoretically, our goal was to shift the discussion back to more fundamental problems of inclusion/exclusion, to which globalisation and the increasing geographical mobility of individuals give new scope.

Empirical results of the article show that the main source of discrepancy between citizenship and electorate is the combination of high rates of nonnational residents (immigrants) in countries in which naturalisation laws make it difficult to access nationality and thus voting rights. This large discrepancy is also not solved by electoral laws since these do usually not grant voting rights to non-nationals. Problems of inclusiveness are therefore strictly linked to conceptions of nationality - who is a member of the national community and who is not-and to conceptions of citizenship — who is a member of the political community and who is not. In principle, it would be possible to imagine changes in electoral laws granting voting rights to citizens without making them nationals and 
therefore address also problems of non-permanent migration and residency. This would make it possible to include citizens in the political community without including them in the national community. It is an instrument that would solve normative conflicts about confusing definitions of who is a national and who is not. It would also solve problems of temporality, since electoral laws could make voting rights for non-nationals dependent upon non-permanent residency. Non-national citizens vote as long as they live and pay taxes in a country, and lose the right as soon as they leave it. This study, thus also points to normative implications for future research and policy-making.

\section{References}

Bartolini, S. (2005) Restructuring Europe: Centre Formation, System Building and Political Structuring Between the Nation State and the European Union, Oxford, Oxford University Press.

Bauböck, R. (2005) 'Expansive Citizenship—Voting Beyond Territory and Membership', PS: Political Science \& Politics, 38, 683-687.

Beckman, L. (2006) 'Citizenship and Voting Rights: Should Resident Aliens Vote?', Citizenship Studies, 10, 153-165.

Bendix, R. (1977) Nation-Building and Citizenship: Studies of Our Changing Social Order, Berkeley, CA, University of California Press.

Blais, A. and André Bodet, M. (2006) 'Does Proportional Representation Foster Closer Congruence Between Citizens and Policy Makers?', Comparative Political Studies, 39, $1243-1262$.

British Council and Migration Policy Group. (2007). 'Migrant Integration Policy Index (MIPEX)', accessed at www.integrationindex.eu on January 11, 2011.

Brubaker, R. (1992) Citizenship and Nationhood in France and Germany, Cambridge, MA, Harvard University Press.

Caramani, D. (2004) The Nationalization of Politics: The Formation of National Electorates and Party Systems in Western Europe, Cambridge, Cambridge University Press.

Costa Lobo, M. (2007) 'Portugal: Extended Voting Rights and Decreasing Participation'. In International Institute for Democracy and Electoral Assistance and Federal Electoral Institute of Mexico (eds) Voting From Abroad: The International IDEA Handbook, Stockholm, International IDEA, pp. 83-88.

Dahl, R. A. (1971) Polyarchy: Participation and Opposition, New Haven, CT, Yale University Press.

Deschouwer, K. (2005) 'Pinball Wizards: Political Parties and Democratic Representation in the Changing Institutional Architecture of European Politics'. In Römmele, A., Farrell, D. M. and Igmazi, P. (eds) Political Parties and Political Systems: The Concept of Linkage Revisited, Westport, CN, Praeger, pp. 83-100. 
Dumont, J-C. and Lemaitre, G. (2005) 'Counting Immigrants and Expatriates in OECD Countries: A New Perspective’. Working Paper No. 25, Paris, OECD Social Employment and Migration.

Gellner, E. (1983) Nations and Nationalism, Ithaca, NY, Cornell University Press.

Golder, M. and Stramski, J. (2010) 'Ideological Congruence and Electoral Institutions', American Journal of Political Science, 54, 90-106.

Green, P. (2007) 'Entitlement to Vote. In International Institute for Democracy and Electoral Assistance and Federal Electoral Institute of Mexico'. (eds) Voting From Abroad: The International IDEA Handbook, Stockholm, International IDEA, pp. $89-103$.

Hammar, T. (1990) Democracy and the Nation State: Aliens, Denizens and Citizens in a World of International Migration, Aldershot, Avebury.

Huber, J. and Powell, G. B. (1994) 'Congruence Between Citizens and Policymakers in Two Visions of Liberal Democracy', World Politics, 46, 291-326.

International Institute for Democracy and Electoral Assistance and Federal Electoral Institute of Mexico (eds) (2007). Voting From Abroad: The International IDEA Handbook, Stockholm, International IDEA.

Koopmans, R., Statham, P., Giugni, M. and Passy, F. (2005) Contested Citizenship: Immigration and Cultural Diversity in Europe, Minneapolis, MN, University of Minnesota Press.

Magnette, P. 2005 (2001). Citizenship: The History of an Idea, Colchester, ECPR Press.

Mansbridge, J. (2003) 'Rethinking Representation', American Political Science Review, 97, 515-528.

Marshall, T. H. (1963) Class, Citizenship and Social Development, Garden City, NY, Doubleday.

OECD (2006) Estimating the Foreign-Born Population on a Current Basis, Paris, Organisation for Economic Cooperation and Development.

Powell, G. B. (2000) Elections as Instruments of Democracy: Majoritarian and Proportional Visions, New Haven, CT, Yale University Press.

Powell, G. B. (2004) 'Political Representation in Comparative Politics', Annual Review of Political Science, 7, 273-279.

Powell, G. B. and Vanberg, G. (2000) 'Election Laws, Disproportionality and the Left-Right Dimension', British Journal of Political Science, 30, 383-411.

Rokkan, S. (1999) State Formation, Nation-Building and Mass Politics in Europe: The Theory of Stein Rokkan, Flora, P., Kuhnle, S. and Urwin, D. W. Oxford, Oxford University Press.

Song, S. (2009) 'Democracy and Non-Citizen Voting Rights', Citizenship Studies, 13, $607-620$. 
Uggen, C. and Manza, J. (2002) 'Democratic Contraction? Political Consequences of Felon Disenfranchisement in the United States', American Sociological Review, 67, 777-803.

Weil, P. (2001) 'Access to Citizenship: A Comparison of Twenty-Five Nationality Laws'. In Alexander, A. and Klusmeyer, D. (eds) Citizenship Today: Global Perspectives and Practices, Washington, DC, Carnegie Endowment for International Peace.

Wüest, A. M. (2004) 'Naturalised citizens as voters: behaviour and impact', German Politics, 13, 341-359. 